\title{
Recent Strategies for Stereoselective Sialylation and Their Application to the Synthesis of Oligosialosides
}

\author{
立体選択的シアリル化反応の戦略とオリゴシアル酸の化学合成
}

\author{
Hanashima, Shinya \\ RIKEN Advanced Science Institute, Structural Glycobiology team, 2-1 Hirosawa, Wako, Saitama 351-0198, Japan \\ FAX: 81-48-467-9620, E-mail: shanashima@riken.jp
}

(Received on March 4, 2011, accepted on March 28, 2011)

Key Words: sialic acid, glycosylation, stereoselectivity, polysialic acid

\begin{abstract}
Sialic acids on the non-reducing terminus of sialylgylcans are abundantly expressed on the surface of mammalian cells. They play vital roles in cell-cell interactions and during infection by pathogenic bacteria and viruses. The chemical synthesis of sialylated glycans has been investigated for more than two decades, and interesting chemistry has been developed for coupling of sialic acid in an $\alpha$-selective manner. Chemoenzymatic approaches are also now available for stereoselective sialylations. This mini-review focuses on very recent advances in stereoselective chemical sialylations and synthesis of natural sialylglycans using novel strategies, especially for the synthesis of the oligo/polysialic acid structure.
\end{abstract}

\section{A. Introduction}

Sialic acids are a family of acidic nine carbon sugars, which are abundant on the non-reducing terminus of glycoproteins and glycolipids on cell surfaces. Sialic acids and sialylglycans on mammalian cells play key roles in cellcell interactions and signal transductions through cell surface sialic acid recognition proteins of the Selectin and Siglec families $(1,2)$. On the other hand, polysialic acid, a homo polymer of sialic acid linked together in an $\alpha(2,8)$-mode on the $\mathrm{N}$-glycan terminus of the neural cell adhesion molecule (NCAM) 1, inhibits interaction by masking of the binding surface of NCAM (3). Such interactions via sialylglycans and binding proteins are integral to the mechanism of inflammation as well as the onset and malignant transformation of cancers. Furthermore, certain types of pathogenic bacteria and viruses bind specific sialylglycans on the mammalian cell surface to initiate infection. Although sialic acids occur ubiquitously from mammals to bacteria, their biological role, especially in bacteria, remains unclear. Polysialic acids are present in mammals and pathogenic bacteria, such as Escherichia coli and Neisseria meningitides (4-6).
要 約

シアル酸は哺乳動物の細胞表面に存在するシアリル化糖 鎖の非還元末端に広く存在している。それらのシアル酸は細 胞間の相互作用や病原性の細菌、ウイルスの感染に重要な役 割を果たしている。シアリル化糖鎖の化学合成は 20 年以上も の間研究されてきて抢り、立体選択的なシアル酸のグリコシ ル化反応に扔いて興味深い手法が開発されている。化学酵素 法に関しても立体選択的なシアル酸の導入に用いることが可 能である。このミニレビューでは、ごく最近報告された化学 的手法を用いた立体選択的シアリル化反応と、それらの新し い反応を用いた天然型のシアリル化糖鎖、特にオリゴシアル 酸やポリシアル酸の合成に焦点をあてて紹介した。

A. はじめに

シアル酸は酸性の 9 炭糖で、細胞表層に存在する糖タン パク質や糖脂質の非還元末端に広く存在している。これらの シアル酸やシアリル化糖鎖は哺乳動物の細胞表面にあって Selectin や Siglec ファミリータンパク質などのシアル酸認識夕 ンパク質を通して細胞間の相互作用やシグナル伝達において 重要な働きをしている $(1,2)$ 。一方、 $\alpha(2,8)$ の結合様式で連なっ たシアル酸のホモポリマーであるポリシアル酸は神経細胞接 着因子 $(\mathrm{NCAM}) 1$ の $N$ 型糖鎖上に存在して、NCAM 上の結合 領域を覆い隠すことでその相互作用を阻害している (3)。その ようなシアリル化糖鎖とその結合タンパク質間での相互作用 は、炎症やある種のガンの発症や悪性化などのメカニズムに 梁く関与している。それらに加えて病原性の細菌やウイルス の一部は哺乳動物上の特定のシアリル化糖鎖を目印として結 合することで感染が抢こる。シアル酸は哺乳動物から細菌類 まで広く存在することが知られているが、特に細菌に扔いて はその機能は不明な点も多い。上述のポリシアル酸は大腸菌 (Escherichia coli) や髄膜炎菌 (Neisseria meningitides) のような細 菌類にも存在が報告されている(4-6)。 

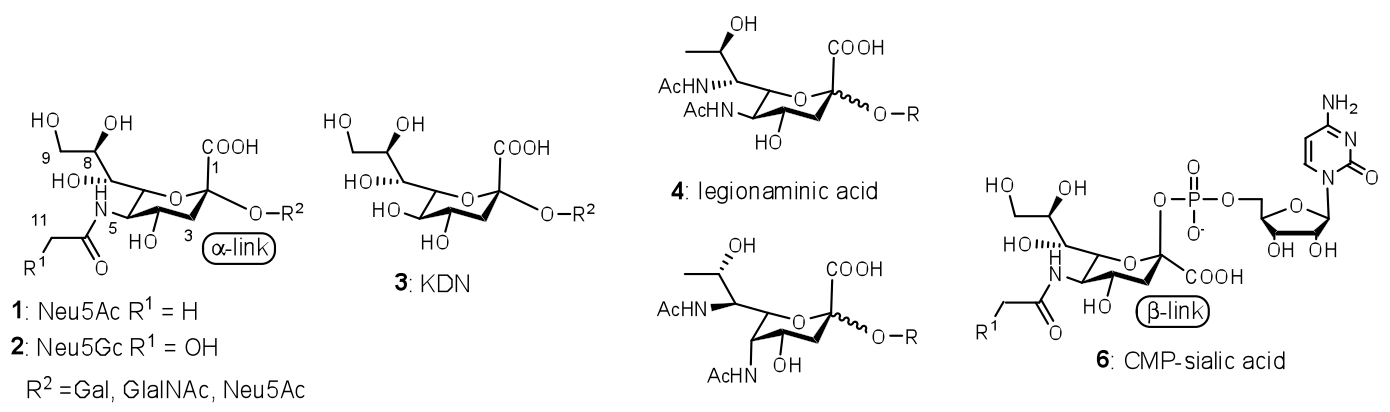

5: pseudaminic acid

Fig. 1. Various structures of sialic acids.

The major species of sialic acids are $N$-acetylneuraminic acid (Neu5Ac) 1, $N$-glycolylneuraminic acid (Neu5Gc) 2 , and $\alpha$-keto-deoxy-D-glycero-D-galactononulosonic acid (KDN) 3 (Fig.1). Some bacteria have unique sialic acids, such as legionaminic acid $\mathbf{4}$ and pseudaminic acid $\mathbf{5}$ which have an amino group at the 7-position instead of a hydroxyl group and are deoxidized at the 9-position. Recently, chemical syntheses of these unique sialic acid units have been reported (7-9).

Mammalian sialic acids have limited linking modes. They are virtually all $\alpha$-linked at the 3,6-position of galactose (Gal), the 6-position of $N$-acetylgalactosamine (GalNAc), or the 8-position of sialic acid. In the biosynthetic pathway of sialylglycans, sialyltransferases mostly use the sugar nucleotide, CMP-sialic acid 6, as a glycosyl donor. CMPsialic acid is the sole species having a $\beta$-linking mode in mammalian glycan. Although the number of linking modes and the structural diversity of sialic acids in mammals are limited, the repertoire expands considerably when other organisms especially bacteria are included. As an example, polysialic acids in bacteria exhibit not only $\alpha(2,8)$-links but also $\alpha(2,4)$ - and $\alpha(2,9)$ - modes. An $\alpha(2,11)$-link at glycolyl group occurs in the Neu5Gc polymer, as initially found in the jelly coating Sea Urchin eggs (10).

Analysis of the function of sialylglycans ideally requires structurally defined homogeneous material. However, isolation of pure glycans from natural sources is difficult because of the heterogeneity and diversity. Chemical and chemoenzymatic syntheses have proved an easier route. Recent developments in the chemoenzymatic approach using bacterial sialyltransferases and related biosynthetic enzymes have overcome the natural substrate specificity, and sialylglycans with structurally modified sialic acid can now be prepared. Such structurally modified sialylglycans are possibly used as enzymatic inhibitors, and as low molecular weight probes in analyzing biological events. On the other hand, chemical sialylation is inherently problematic due to the low reactivity of the tertiary anomeric center of the building block with its electron-withdrawing ester group. Additionally, the non-participating group at the 3-position has hampered
主要なシアル酸の分子種としては $N$-アセチルノイラミン 酸 (Neu5Ac) 1、N-グリコリルノイラミン酸 (Neu5Gc) 2、KDN 3 などが挙げられる(図 1)。加えて、ある種のバクテリアはレ ジオナミン酸 4 やシューダミン酸 5 のような 7 位に水酸基の 代わりにアミノ基をもち、かつ 9 位デオキシ構造をとるシア ル酸をもつものも知られている。これらのユニークなシアル 酸分子種に関する合成も近年報告されている (7-9)。

哺乳動物ではシアル酸の結合様式は限られている。シアル 酸は主にガラクトース (Gal)の 3,6 位、N-アセチルガラクトサ ミン (GalNAc) の 6 位、シアル酸自身の 8 位に $\alpha$ 結合している。 シアリル化糖鎖の生合成に扔いて、シアル酸転移酵素は CMPシアル酸 6 を唯一の供与体基質としている。このCMP- シア ル酸はまた、哺乳動物に扔いて $\beta$ 結合をもつ唯一の分子種で ある。このように哺乳動物のシアル酸の構造的な多様性と結 合様式は限られていることと比較して、他の生物種、特に細 菌類に目を向けるとシアリル化糖鎖は多様な構造と結合様式 をもつ。一例を挙げると、細菌のポリシアル酸は $\alpha(2,8)$ だけで なく $\alpha(2,4) や \alpha(2,9)$ の結合様式もとることが可能である。加え て、シアル酸の分子種がNeu5Gc である場合はグリコリル基 を介して $\alpha(2,11)$ の結合様式もとることができる。この $\alpha(2,11)$ の結合様式をもつ Neu5Gc ポリマーはウニの卵の表層から発 見された (10)。

このようなシアリル化糖鎖の機能を解析する場合、均一で 構造が明らかなサンプルを用いることが理想的である。しか しながら天然に存在する糖鎖は一般に不均一で構造多様性を もつため、望む純粋な糖鎖構造を単離してくることは困難な 場合も多い。そのため化学的あるいは化学 - 酵素的合成法を用 いることが望まれる。近年、化学 - 酵素的合成法は細菌のシア ル酸転移酵素や関連する生合成酵素を利用することでその基 質特異性を乗り越えて、修飾されたシアル酸の導入も可能に した(11)。そのような構造的に修飾されたシアリル化糖鎖は酵 素阻害剂や生命現象を明らかにする低分子プローブとしての 利用が期待される。一方、化学的シアリル化反応は三級のア ノマー中心ならびに電子吸引性のエステル基がアノマー位に 存在するため、供与体の反応性の低さが大きな問題のひとつ であった。くわえて隣接基関与により立体制御できる基が存 在しないことから、望む $\alpha$ 体を優先して高収率で得ることは 
attainment of $\alpha$-selectivity and good yield.

In this minireview, very recent advances in the chemical sialylation approach, including our studies, are described. Additionally, remarkable results in the application of these strategies especially in the synthesis of oligo/ polysialic acid are summarized.

\section{B. C-1 Auxiliary Assisted Sialylation Reactions}

Over the last two decades, important new chemistry has come to light that improves the reactivity and stereochemistry in sialylation reactions (11-14). One of the most promising strategies to control stereochemistry is to insert an auxiliary group. Such artificial groups are usually introduced at either the $\mathrm{C}-3$ or $\mathrm{C}-1$ position. Insertion at the $\mathrm{C}-3$ position provides excellent $\alpha$-selectivity and coupling yield, but removal of the C-3 auxiliary has been problematic in some cases. Strategies involving C-3 auxillaries are now very sophisticated and details are described in a review by Boons (12). C-1 auxiliaries have also been explored for the formation of the $\alpha$-sialoside, which presumably work through intermediates having either direct or solvent-assisted coordination with the auxiliaries (Fig. 2A). Advantages of a C-1 participation strategy include the mild chemical conditions required for introducing a functionality via the ester bond, the protective effect of the introduced group, and the mild hydrolyzing conditions for its removal. Since the initial attempts to demonstrate viability of the concept (15), efforts have turned to tuning of the auxiliary. Building blocks that possess esters including $-\mathrm{O}\left(\mathrm{CH}_{2}\right)_{2} \mathrm{CN},-\mathrm{OCH}_{2} \mathrm{CONMe}_{2}$ and -NHMe have
困難であった。

このミニレビューでは特に近年報告された化学的シアリ ル化反応に焦点を当て、筆者の研究と併せてその戦略をまと めた。また新たな合成戦略に加え、それらの応用例として特 にオリゴ/ポリシアル酸の化学合成に焦点を絞って紹介する。

\section{B. C-1 補助基を用いたシアリル化反応}

化学的シアリル化反応はこの 20 年以上盛んに研究が進め られており、その過程で反応性や立体選択性を改善する重要 なケミストリーが発見されてきた。この分野では既に優れた 総説が発表されており、本総説では我々の戦略を含めた最近 の報告をまとめた(11-14)。シアリル化反応における立体化学 を制御するうえで補助基を用いることは有力な手法の一つと いえる。そのような隣接基関与を期待できる補助基は C-3 位ま たは C-1 位に導入することが可能である。C-3 位への修飾は優 れた $\alpha$ 選択性とカップリング収率を示すが、反応後、C-3 位の 補助基の除去が必要となる。C-3 補助基を用いる優れた手法は Boons らの総説内にまとめられているためそちらも参考にして いただきたい (12)。一方、C-1 位への補助基の導入による立体 選択的シアリル化反応に関しても研究されている。本手法で は C-1 位からの直接的、あるいはニトリル等の溶媒が関与す る形で隣接基関与がおこった中間体を経て反応が進行すると 考えられている(図 2A)。C-1 隣接基関与法の利点として、エ ステル結合を介して温和な化学反応条件で官能基が導入でき、 それら補助基は保護基として機能して、合成の最終段階に温 和な加水分解条件で除去することができる。はじめにそのコ ンセプトの可能性が報告されて以来 (15)、適切な補助基の探索

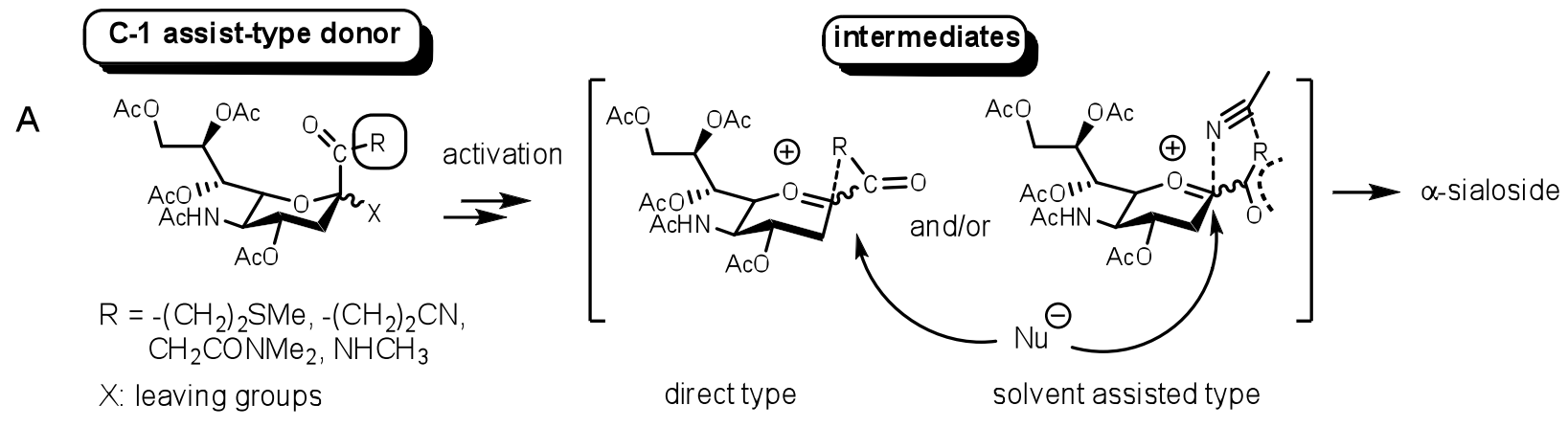

B

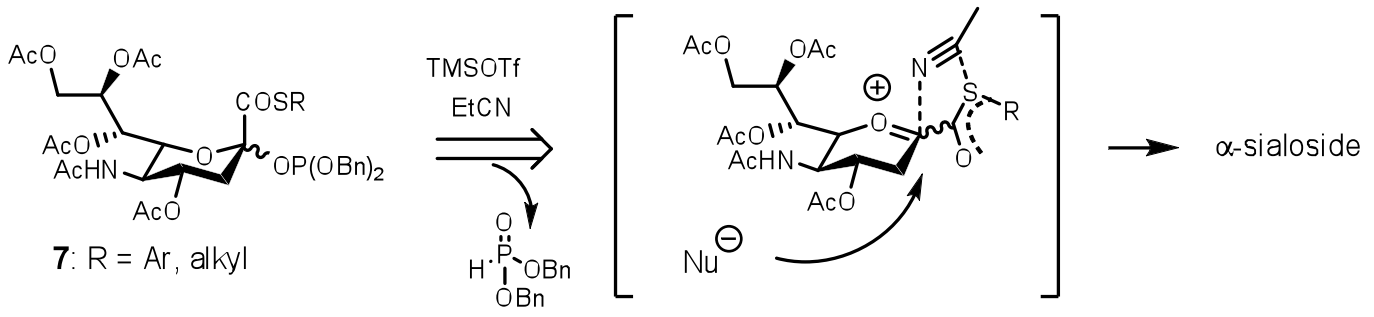

Fig. 2. Structure of sialic acid building blocks for C-1 participation strategy and plausible reaction mechanism. A, General procedures for $\mathrm{C}-1$ participation strategy; $\mathrm{B}$, Thioester participation strategy. 
been favored for producing the $\alpha$-sialoside bond (16-19).

Our group also employed a C-1 participation strategy (Fig. 2B) (20). We chose a thioester as the participating auxiliary, because it was expected to react with nucleophiles $\left(\mathrm{Nu}^{-}\right)$through both the intermediates shown in Fig. 2A. The thioester moiety of 7 was readily introduced via ethylchloroformate activation of the carboxyl group at the $\mathrm{C} 1$-position. Highly reactive phosphite was chosen as an anomeric leaving group. Various thioester building blocks 7 were subjected to sialylation reactions, and finally phenylthioester was found to exhibit the best $\alpha$-selectivity in propionitrile at low temperature. The building block having thioester was then used for sialylation reactions with various acceptor alcohols, and $\mathrm{C} 6-\mathrm{OH}$ of galactose acceptors provided a best case $87 \%$ yield with an $\alpha / \beta$ ratio of $9: 1$. In sialylation to the 3-position of galactose, the use of a 4,6-di-O-benzyl galactal acceptor provided $81 \%$ yields with an $\alpha / \beta$ ratio of 9:1 to give the desired sialoside. While the C-1 participation strategy results in excellent $\alpha$-selectivity for the reactive C6$\mathrm{OH}$ group of a galactose acceptor, only limited kinds of C3$\mathrm{OH}$ galactose acceptor have provided satisfactory yield and stereoselectivity to date.

\section{C. $N$-5 Modified Sialic Acid Building Blocks}

On the other hand, direct sialylation strategies are making remarkable progress. The key finding for improving the $\alpha$-selectivity and reactivity of the sialic acid building block has been substitution of the protecting group at $\mathrm{C} 5$-amino group with $\mathrm{N}, \mathrm{N}$-diacetyl or $\mathrm{N}$-trifluoroacetamide (TFA) (Fig. 3) (21-23). Following reports where the building blocks carry various C-5 amino groups including azide, cyclic imide and carbamate protections show promising results (24-27). $N$-Tri chloroethoxycarbonyl (Troc) protections have been especially investigated because of the favorable stability under the conditions used for glycosylation and the various protecting group manipulations $(28,29)$. The $N$-Troc protected sialic acid building blocks exhibit better reactivity than the corresponding $N$-acetyl, and $N$-TFA protected species. However, the $\alpha$-selectivity and reaction yields of the sialylation reactions were rather poor especially when the 3-position of the galactose acceptor was employed. We tackled this issue
が抗こなわれてきた。その結果、- $\mathrm{O}\left(\mathrm{CH}_{2}\right)_{2} \mathrm{CN},-\mathrm{OCH}_{2} \mathrm{CONMe}_{2}$ のようなエステルや $\mathrm{NHMe}$ のようなアミドを持つ供与体が $\alpha$ シアル酸結合形成を促進した(16-19)。

われわれもC-1 隣接基関与法に関する研究をおこなってき た (図 2B) (20)。図 2A に示した二つの中間体のどちらをもと りうる経路で求核剤 $(\mathrm{Nu})$ との反応が進行すると期待して、チ オエステルを C-1 補助基として用いることにした。目的のチ オエステルは C-1 位カルボン酸をクロロ蟻酸エチルで活性化 して導入した。さらにアノマー位の脱離基として反応性の高 いホスファイト基を用いた。さまざまなチオエステル構造を もつ供与体 7 をシアリル化反応に供した結果、フェニルチオ 基をもつ供与体がプロピオンニトリル中低温下で最も高い $\alpha$ 選択性を示した。さまざまな受容体に対してフェニルチオ基 をもつ供与体との反応を試みた結果、ガラクトース 6 位に対 しては最も良いもので収率 87\% かつ 9:1 の $\alpha$ 選択性を与えた。 一方ガラクトースの 3 位に対しては 4,6-di-O-benzyl galactal を 受容体として用いた場合、81\%の収率と 9:1の $\alpha$ 選択性で目 的のシアリル化体を与えた。このようにC-1 補助基を用いる 手法はガラクトースの 6 位水酸基を受容体にした場合に高い 立体選択性と収率を与えるが、3 位水酸基を受容体にした場合、 高い選択性と収率を与える例は限られている。

\section{5 位修飾型シアル酸供与体}

一方、補助基を用いない直接的なシアリル化反応が近年 注目すべき成果を上げている。シアル酸の 5 位アミノ基の保 護基を $N, N$ - ジアセチルや $N$-トリフルオロアセチル (TFA) 基 へと変換することで、供与体の $\alpha$ 選択性や反応性が改善する ことが見出された(図 3) (21-23)。それらの報告に引き続きア ジド、フタルイミドなどのイミド、カーバメート型の保護基 を導入した供与体を用いた反応が研究されて、その有用性が 報告されている (24-27)。そのような保護基の中で特に $N$-trichloroethoxycarbonyl (Troc) 基で保護したシアル酸供与体は、 グリコシル化反応条件下ならびに他の保護基の除去条件下で の安定性に優れており、反応性の面とあわせた利点からよく 研究されてきた $(28,29)$ 。N-Troc 保護したシアル酸供与体は対 応する $N$-アセチルや $N$-TF A で保護した供与体に比べ高い反 応性を示す。しかしながら、これらの供与体を用いたシアリ ル化反応に扔いて特にガラクトースの 3 位を受容体とした場 合、 $\alpha$ 選択性が高くない場合も少なくない。われわれはこの

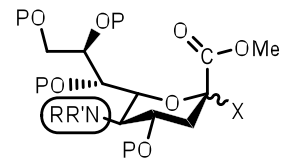

$\mathrm{R}=\mathrm{TFA}, \mathrm{N}-$ Troc, Boc, Fmoc, Alloc $\mathrm{R}^{\prime}=\mathrm{H}$ or $\mathrm{Ac}$

$X=S-A r$, S-alkyl, phosphite, etc

$\mathrm{P}=$ protecting group

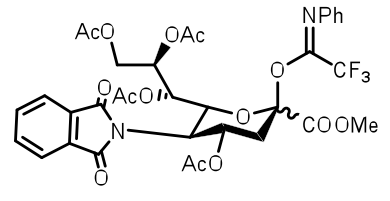

12

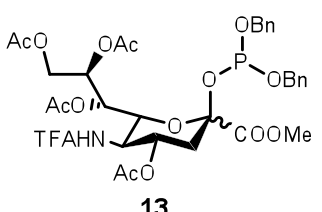

13

Fig. 3. The structures of $N$-substituted sialic acid building blocks. 


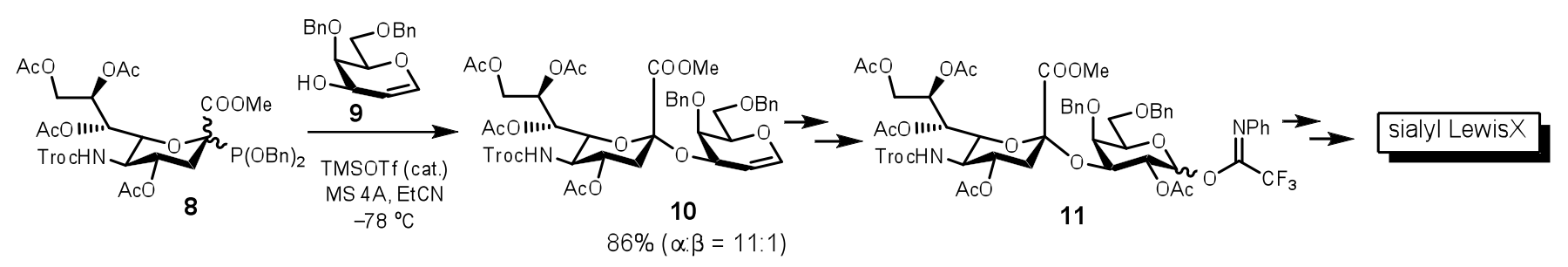

Scheme 1. Synthesis of sialyl LewisX using $N$-Troc building block 8 and the galactal acceptor 9.

by increasing the reactivity of the $N$-Troc protected sialyl building blocks using highly reactive phosphite leaving groups (Scheme 1) (30). The phosphite leaving group was readily introduced from a phenylthio building block in two steps, and acceptor suitability were screened using the $N$-Troc sialyl phosphite building block $\mathbf{8}$. The building block $\mathbf{8}$ was readily activated even at $-78{ }^{\circ} \mathrm{C}$ in propionitrile using TMSOTf as the Lewis acid. It provided an excellent yield and good stereoselectivity towards the 6-position of galactose receptors, comparable to that achieved using the parent phenylthio building blocks. Towards the 3-position of the galactose, galactal 9 was best as an acceptor substrate and provided the desired sialoside precursor 10 in $86 \%$ yield and the $\alpha / \beta$ ratio reached 11:1. The unsaturated bond on galactal $\mathbf{1 0}$ was readily transformed into galactose configurations via oxidation using $\mathrm{PhI}(\mathrm{OAc})_{2}$ and $\mathrm{BF}_{3}-\mathrm{Et}_{2} \mathrm{O}$, and the further steps provided the disaccharide building block 11. The building block $\mathbf{1 1}$ was eminently suitable for the synthesis of sialyl Lewis ${ }^{\mathrm{X}}$ and other sialylglycans, which are involved in Influenza virus infections (30,31).

The $N$-phthalimide protected building block having a $N$-phenyltrifluoroacetimidate leaving group 12, developed by Tanaka-Fukase, is applicable to microreactor syntheses of various sialylglycans $(32,33)$. A remarkable result on the application of microfluidic chemistry is the improved stereoselectivity of the sialylation reaction under microflow conditions. Lin and co-workers developed a $N$-TFA building block having a phosphite leaving group 13, and applied it in the synthesis of a $\alpha(2,9)$ oligosialic acid tetramer (34). They first obtained the $\alpha(2,9)$ sialic acid dimer with good yield and $\alpha$-selectivity, and then a dimer + dimer coupling strategy achieved the synthesis of the $\alpha(2,9)$ sialic acid tetramer with $58 \%$ yield $(\alpha / \beta=1.6 / 1)$.

\section{4,5-Oxazolidinone Building Blocks for Oligosialic Acid Synthesis}

In the case of the $N-5$ modified sialic acid building block, protection with 4,5-oxazolizinone, separately developed by the groups of Tanaka-Takahashi, Crich, and De Meo exhibited excellent $\alpha$-selectivity and yields (Fig. 4) (3537). With the $\mathrm{C} 6-\mathrm{OH}$ galactose acceptor, the building blocks
点を解決すべく $N$-Troc 保護体にさらに高い反応性を付与して 低温で活性化できるようホスファイトを脱離基として用いる ことにした (Scheme 1) (30)。ホスファイト基はフェニルチオ 基をもつ供与体から二段階で容易に変換可能で、得られたシ アル酸供与体 8 を用いて各種ガラクトース受容体との反応性 を比較した。供与体 8 はー $78{ }^{\circ} \mathrm{C} に$ にいてプロピオニトリル中 TMSOTfをルイス酸として用いて容易に活性化することが可 能であった。ガラクトース受容体の 6 位に対するシアリル化 反応は、フェニルチオ基をもつ供与体と同様に高い収率と立 体選択性を示した。一方ガラクトース 3 位に対してはガラク タール9を受容体基質として用いた場合最も良い結果を与え、 望むシアロシド前駆体 $\mathbf{1 0}$ を $86 \%$ の収率で $\alpha$ 体を与えその選 択性は 11:1 の $\alpha / \beta$ 比であった。ガラクタールの不飽和結合は $\mathrm{PhI}(\mathrm{OAc})_{2}$ と $\mathrm{BF}_{3}-\mathrm{Et}_{2} \mathrm{O}$ を用いて酸化しガラクトースの立体配 置とし、二糖供与体 11 へと導いた。この供与体 11 を用いてシ アリルルイス Xやインフルエンザの感染などに関与している シアリル化糖鎖の合成を達成した $(30,31)$ 。

アミノ基をフタルイミド基で保護し、脱離基として $N$-フェ ニルトリフルオロアセトイミデートをもつ供与体 12 は田中 深瀬らにより精力的に研究が進められ、マイクロ流路を用い た合成を適用してさまざまなシアリル化糖鎖が合成可能であ ることが示された $(32,33)$ 。マイクロ流路化学を適用した反応 で興味深いことの一つとして、立体選択性が向上する場合が あることが挙げられる。Lin らは N-TFA をアミノ基の保護基 としてもちホスファイトを脱離基とした供与体 $\mathbf{1 3}$ 用いて 4 量体の $\alpha(2,9)$ シアル酸の合成に取り組んだ (34)。2 量体形成は 立体選択的かつ高収率で反応が進行し、続く 2 量体 +2 量体 のカップリング反応による 4 量体を収率 $58 \%$ で立体選択性は $\alpha / \beta=1.6 / 1$ で得た。

\section{4,5- オキサゾリジノン型供与体を用いたオリゴシアル酸合} 成

$N-5$ 位の修飾によるシアル酸供与体に関する研究はさら に進められて、田中 - 高橋、Crich、De Meoらにより別途開 発された 4,5- オキサゾリジノン型のシアル酸供与体が非常に 高い $\alpha$ 選択性ならびに反応収率を示すことが報告された(図 4)(35-37)。それらの供与体を用いることで、ガラクトース 6 位 へのシアリル化反応に扔いてはニトリル溶媒を用いない系に 


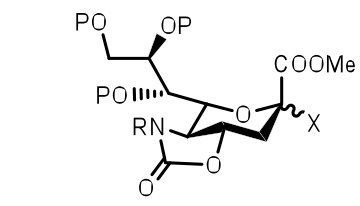

$\mathrm{R}=\mathrm{H}$ or $\mathrm{Ac}$

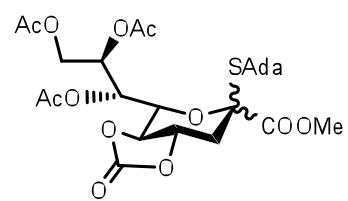

24

$X=\mathrm{SAr}$, S-adamantyl, phosphate

Fig. 4. Structure of 4,5-oxazolidinone and carbonate protected sialic acid building blocks.

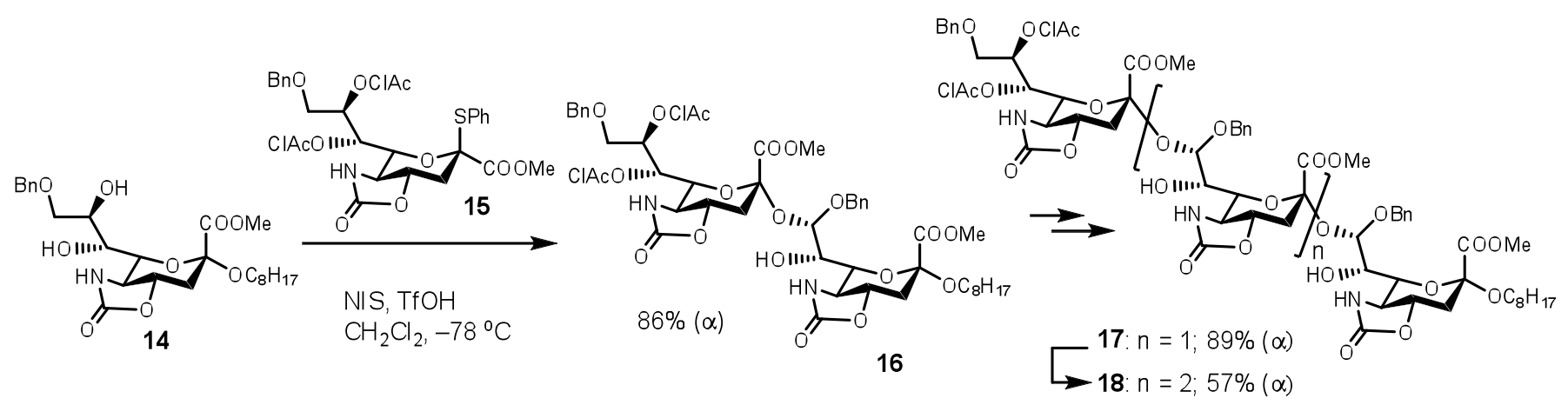

Scheme 2. Synthesis of tetra- $\alpha(2,8)$-sialic acid by the Tanaka-Takahashi's approach.

provide excellent $\alpha$-selectivity without the nitrite effect $(38,39)$. The 4,5-oxazolidinone locked building blocks especially exhibited remarkable coupling yields and $\alpha$-selectivity in forming the $\alpha(2,8)$ sialyl bond (Scheme 2). Building block $\mathbf{1 5}$ used with 7,8-diol acceptor $\mathbf{1 4}$ gives the desired disialic acid 16 with $86 \%$ yield in an $\alpha$-selective manner. Repetitions of deprotection of chloroacetyl ( $\mathrm{ClAc}$ ) groups and sialylation reactions using building block results in $\alpha(2,8)$-oligosialic acid trimer $\mathbf{1 7}$ and tetramer $\mathbf{1 8}$ in $89 \%$ and $57 \%$ yield respectively (35). They also synthesized ganglioside GP1c having oligosialic acid branches at non-reducing terminus of the glycan chain (40). Synthesis of $\alpha(2,9)$-oligosialic acid came from using either a linear strategy for tetramer or a onepot glycosylation strategy with resin-capture purifications using the combination of $S$-benzoxazolyl (SBox) and SEt leaving groups for the trimer (Scheme 3) $(41,42)$. Initial activation of the SBox group on 19 by AgOTf in the presence of acceptor $\mathbf{2 0}$ provided the disaccharide $\mathbf{2 1}$ with good yield
おいても高い $\alpha$ 選択性を示した(ニトリル効果: 38,39$)$ 。特に 注目すべき点は、この 4,5- オキサゾリジノン型供与体は $\alpha(2,8)$ 結合の形成に有用な成果を挙げていることである (Scheme 2)。 4,5- オキサゾリジノン型シアル酸供与体 $\mathbf{1 5}$ は、7,8 ジオール型 の受容体 14 との反応で望む $\alpha(2,8)$ シアル酸 2 量体 16 を $\alpha$ 選 択的に $86 \%$ の収率で与えた。続くクロロアセチル (ClAc) 基の 脱保護、供与体 15 をもちいたシアリル化反応を繰り返すこと により、3 量体 17 を 89\%、4 量体 $\mathbf{1 8}$ を57\%の収率でそれぞ れ得た (35)。彼らはまた糖鎖の非還元末端にオリゴシアル酸 をもつガングリオシド GP1cの合成を達成した $(40) 。 \alpha(2,9)$ オ リゴシアル酸の合成に関しても挑戦し、直線的な合成により 4 量体の合成、S-ベンゾオキサゾリル (SBox) 基と SEt 基の連 続的活性化法を利用したワンポットグリコシル化と固相樹脂 による釣り上げを併せた方法を用い 3 量体の合成を達成した (Scheme 3)(41,42)。19の SBox 基はトリフルオロメタンスルホ ン酸銀によって活性化されて 20 とカップリングして 2 糖を高 收率かつ $\alpha$ 選択的に与えた。得られた 2 糖 $\mathbf{2 1}$ の SEt 基は NIS

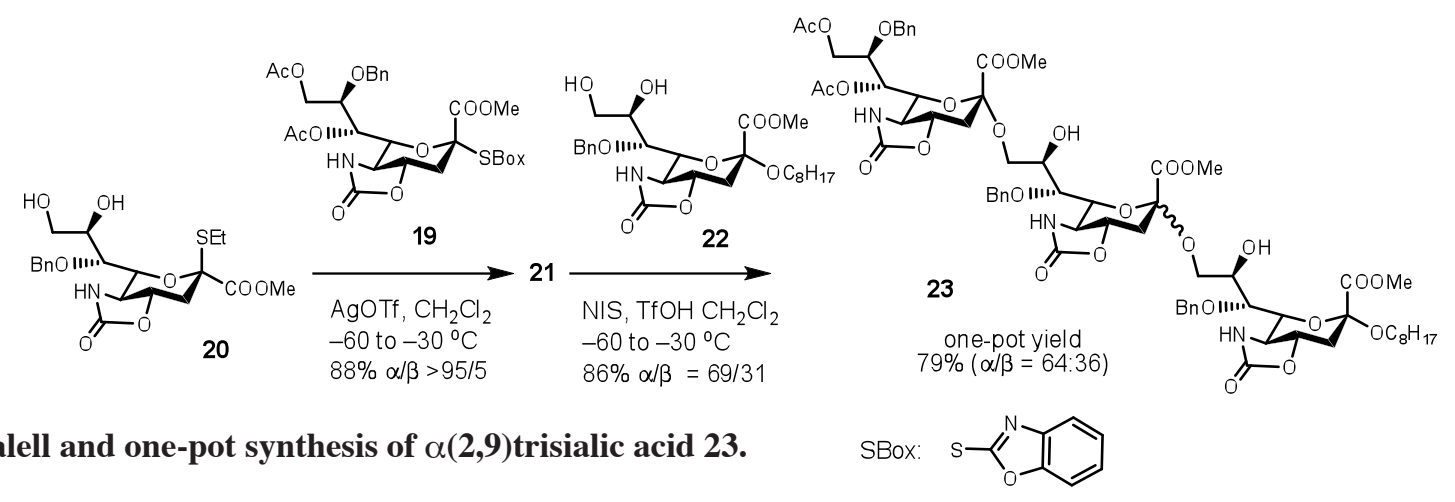

Scheme 3. Paralell and one-pot synthesis of $\alpha(2,9)$ trisialic acid 23. 

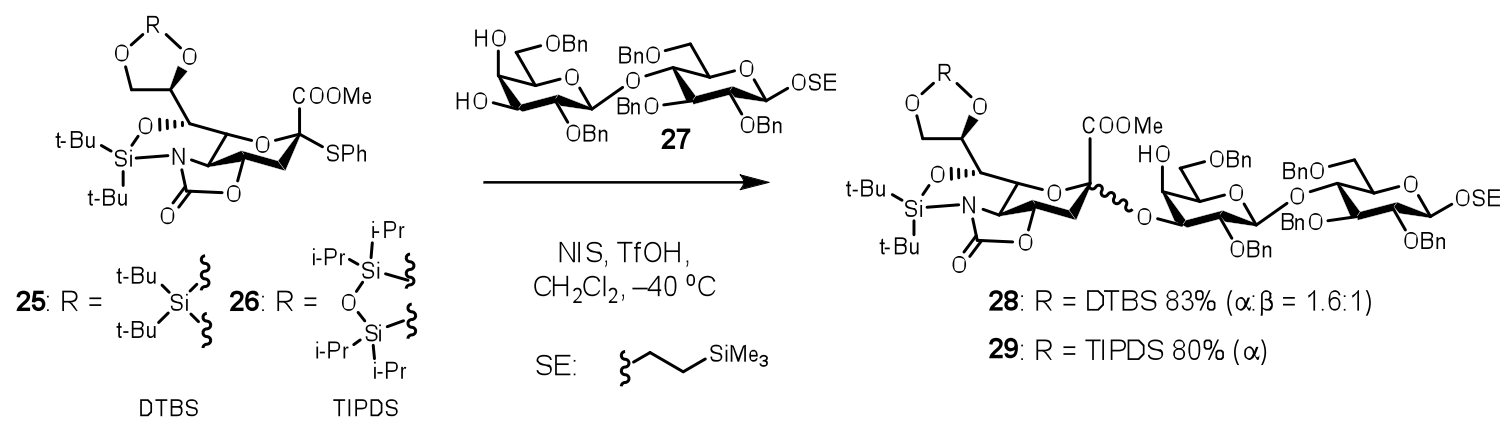

Scheme 4. Sialylation reaction using oxazolidinone/DTBS double-locked building blocks 25 and 26.

and $\alpha$-selective manner. Then, the SEt leaving group of the disaccharide $\mathbf{2 1}$ was readily activated by NIS and TfOH and coupled with diol acceptor $\mathbf{2 2}$ to give trisaccharide $\mathbf{2 3}$ in $86 \%$ yield, however, the ratio of $\alpha: \beta$ was $69: 31$. Crich and coworkers applied the cyclic 4,5-lock strategy for stereoselective sialylation of KDN using carbonate type protection (43). The building block $\mathbf{2 4}$ having a S-adamantyl (SAda) leaving group was activated by NIS and TfOH in $\mathrm{CH}_{2} \mathrm{Cl}_{2} / \mathrm{MeCN}$ at $-78{ }^{\circ} \mathrm{C}$ to give the desired disaccharide. The reaction proceeded with $\alpha$-selective manner for both $\mathrm{C} 6-\mathrm{OH}$ and $\mathrm{C} 3-\mathrm{OH}$ of galactose acceptors. The various applications and experimental examples of $\mathrm{N}-5$ modified building blocks including the use of the 4,5-oxazolidinone locked form are well summarized by De Meo (44).

Our group modified the 4,5-oxazolidinone locked sialic acid building blocks by appending further ring-fixing protection using cyclic silylene at the 5,7-positions. (Scheme 4) (45). To synthesize such double-locked sialic acid building blocks, the pyranose-ring constraining cyclic 5,7di-tert-butylsilylene (DTBS) groups and either 8,9-DTBS or 8,9-\{1,3-(1,1,3,3-tetraisopropyl)-disiloxanylidene\} (TIPDS) groups for the cyclic protection of side-chain hydroxyl groups were introduced to the 4,5-oxanolidinone locked sialic acid in one or two steps to give $\mathbf{2 5}$ and $\mathbf{2 6}$. The doublelocked building blocks $\mathbf{2 5}$ and $\mathbf{2 6}$ were activated with NIS and $\mathrm{TfOH}$ at $-40{ }^{\circ} \mathrm{C}$ in $\mathrm{CH}_{2} \mathrm{Cl}_{2}$. Building blocks 25 and 26 showed excellent $\alpha$-selectivity toward the 6-OH of the galactose acceptor, comparable to previous reports in which 4,5-oxanolidinone locked sialic acid building blocks were used. Towards the $3-\mathrm{OH}$ of galactose, the use of $2-O-\mathrm{Bn}$ protected galactose and lactose acceptor provided excellent $\alpha$-selectivity, however, the relatively less reactive $2-O-\mathrm{Bz}$ protected galactose acceptor indicated $\beta$-selectivity. In the coupling with lactose acceptor $\mathbf{2 7}$, the use of building block $\mathbf{2 5}$ having 8,9-DTBS protection produced trisaccharide $\mathbf{2 8}$ with an $\alpha: \beta$ ratio of 1.6:1. In contrast, the use of $\mathbf{2 6}$ having 8,9-TIPDS produced 29 in $80 \%$ yield with $\alpha$-selective manner. Screening of the acceptors indicated that the 5,7-DTBS lock enhanced $\alpha$-selectivity of the sialylation reactions,
と $\mathrm{TfOH}$ を用いて活性化することで受容体 $\mathbf{2 2}$ と反応し 3 糖工 ニット 23 を 86\% の収率で与え、その $\alpha: \beta$ 選択性は 69:31 であっ た。Crichらはこの 4,5- 環状保護基を用いた手法に関して炭 酸エステルを利用して KDN に適用した (43)。S-アダマンチル (SAda) 基を脱離基として持つ供与体 $\mathbf{2 4}$ は、 $\mathrm{CH}_{2} \mathrm{Cl}_{2} / \mathrm{CH}_{3} \mathrm{CN}$ 中 - $78{ }^{\circ} \mathrm{C}$ でNIS と TfOH を用いて活性化することで望む 2 糖 を与えた。反応はガラクトース受容体の 3 位、6 位水酸基の双 方に対して $\alpha$ 選択的に進行した。これら 4,5-オキサゾリジノ ン型を含む 5 位の修飾型シアル酸供与体を用いたシアリル化 反応はDe Meoらによりまとめられているので、そちらも参 考にしていただきたい(44)。

われわれはこの4,5- オキサゾリジノン型シアル酸供 与体にさらに環状のシリレン基で5,7-位を保護した二重架 橋型シアル酸供与体 25, 26 を開発した (Scheme 4)(45)。本 供与体の合成は 4,5- オキサゾリジノン型シアル酸供与体 に5,7位に環状に配してピラノース環を固定化するdi-tertbutylsilylene(DTBS) 基、8,9 位の側鎖水酸基は環状の DTBS 基 または 1,3-(1,1,3,3-tetraisopropyl)-disiloxanylidene (TIPDS) 基を 1 段階または 2 段階で導入して容易に供与体 $\mathbf{2 5}, \mathbf{2 6}$ を得た。二 重架橋型のシアル酸供与体 $\mathbf{2 5}$ または 26 は NIS と TfOH を用 いて $\mathrm{CH}_{2} \mathrm{Cl}_{2}$ 中 $-40{ }^{\circ} \mathrm{C}$ で活性化することが可能で、ガラクトー 久受容体の 6 位に対して非常に高い $\alpha$ 選択性を示した。これ は前述のフェニルチオ基を脱離基とした 4,5- オキサゾリジノ ン型供与体と同様の結果といえる。一方ガラクトース受容体 3 位に対する反応では、 2 位を $\mathrm{Bn}$ 基で保護した受容体に対して は高い立体選択性を示したが、2 位を $\mathrm{Bz}$ 基で保護した反応性 の低い受容体に対しては望まない $\beta$ 選択性を示した。ラクトー 又受容体 27 を用いたシアリル化反応では、8,9 位をDTBS で 保護したシアル酸供与体 $\mathbf{2 5}$ は 3 糖 $\mathbf{2 8} \alpha: \beta=1.6: 1$ の選択性で 与えた。一方 8,9 位を TIPDS 基で保護した供与体 $\mathbf{2 6}$ を用いた 場合は 3 糖 29 を $80 \%$ かつ $\alpha$ 選択的に与えた。このように 5,7 位 -DTBS 保護による環の固定化はシアリル化反応において $\alpha$ 選択性を高めること、さらに 8,9 位の嵩高い TIPDS 基での保 
and protection of the 8,9-hydroxyl groups by bulky TIPDS exhibited better $\alpha$-selectivity than DTBS. These doublelocked sialic acid building blocks produced core trisaccharides 28, which were used for the synthesis of the glycan-part of the unique ganglioside AG2, which has further sugar-elongation at the 4-position of the sialic acid unit (46).

Recently, a new sialic acid building block having a phosphate leaving group combined with 4,5-oxazolidinone protection was reported (47). The phosphate leaving group was introduced via glycosylation reactions using a $\mathrm{SPh}$ sialic acid building block. The group has an advantage for sequential activation when used in combination with a thioglycoside (48). The phosphate building block was readily activated by TMSOTf at $-78{ }^{\circ} \mathrm{C}$ to produce a sialyl $\alpha(2,3) \mathrm{Gal}$ unit in a highly stereoselective manner. The sequential activation property was used advantageously in their programmable onepot glycosylations to give various oligosaccharides including SSEA-4 hexasaccharide.

\section{E. Stereoselective Sialylation Using an Acceptor with Constrained Conformation}

Recently, a unique acceptor-structure based strategy has been reported and 1,5-lactamized sialic acid $\mathbf{3 0}$ has been suggested to be a good acceptor due to exposing hydroxyl groups by the ring-conformational constraining effect (49). This 1,5-lactamization acceptor $\mathbf{3 0}$ combined with $N$-TFA protected $N$-phenyltrifluoroacetimidate building block $\mathbf{3 1}$ allowed for the synthesis of $\alpha(2,8)$ oligosialic acid tetramer (Scheme 5) (50). The building block 31 was activated with TMSOTf at $-80{ }^{\circ} \mathrm{C}$, provided disaccharide 32 in $86 \%$ yield with an $\alpha: \beta$ ratio of $16: 1$. Then, the TFA and ClAc groups were simultaneously deprotected by treatment with base, and following an intra-residual lactamization reaction using $O$-benzotriazole- $N, N, N^{\prime}, N^{\prime}$-tetramethyl-uronium-hexafluoro-
護は DTBS 基に比べて高い $\alpha$ 選択性を示すことを明らかにし た。これら二重架橋型のシアル酸供与体を使い得られたコア 3 糖 28 は、シアル酸残基の 4 位からさらに糖鎖が伸長したユニー クな構造をもつガングリオシド A G2 の 5 糖構造の合成に応用 した (46)。

近年、4,5- オキサゾリジノン保護体のうちホスフェートを 脱離基としてもつ供与体が報告された (47)。ホスフェート脱離 基は SPh 基をもつシアル酸供与体からグリコシル化反応によ り導入された。ホスフェート基はチオ糖と組み合わせて用い ることで連続的な活性化法を用いた合成が可能となった (48)。 ホスフェート基はTMSOTfを用いて $-78{ }^{\circ} \mathrm{C} て ゙$ 容易に活性化 可能で、還元末端に SPh 脱離基をもつシアリル $\alpha(2,3)$ ガラク トースのユニットに関して高い収率と $\alpha$ 選択性を示した。こ のような連続的活性化法の利点を生かし、彼らのワンポット グリコシル化反応と併せることで 6 糖 SSEA-4 を含む種々のシ アリル化糖鎖の合成を達成した。

\section{E. 配座を固定した受容体を用いる立体選択的シアリル化反応} 2005 年にユニークな受容体構造を基盤とした戦略、すな わち 1,5- ラクラム化シアル酸 $\mathbf{3 0}$ が 8 位へのシアリル化反応に おいて良い受容体となることが報告された $(49)$ 。その理由と してはラクタム化によりピラノース環のコンホメーションが 固定化される効果と考えられる。N-TFA 保護され $N$ - フェニ ルトリフルオロアセトミデートを脱離基としたシアル酸供与 体 $\mathbf{3 1}$ とラクタム化受容体 $\mathbf{3 0}$ を組み合わせることで $\alpha(2,8)$ オ リゴシアル酸 4 量体の合成が達成されている (50)。供与体 $\mathbf{3 1}$

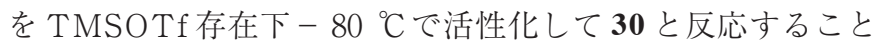
で 2 糖 32 を 86\% の収率、 $\alpha: \beta=16: 1$ の選択性で与えた。続いて $\mathrm{TFA}$ 基ならびに $\mathrm{ClAc}$ 基を塩基性条件下一気に除去したのち、 HBTUでカルボキシル基を活性化して残基内ラク夕ム化をお

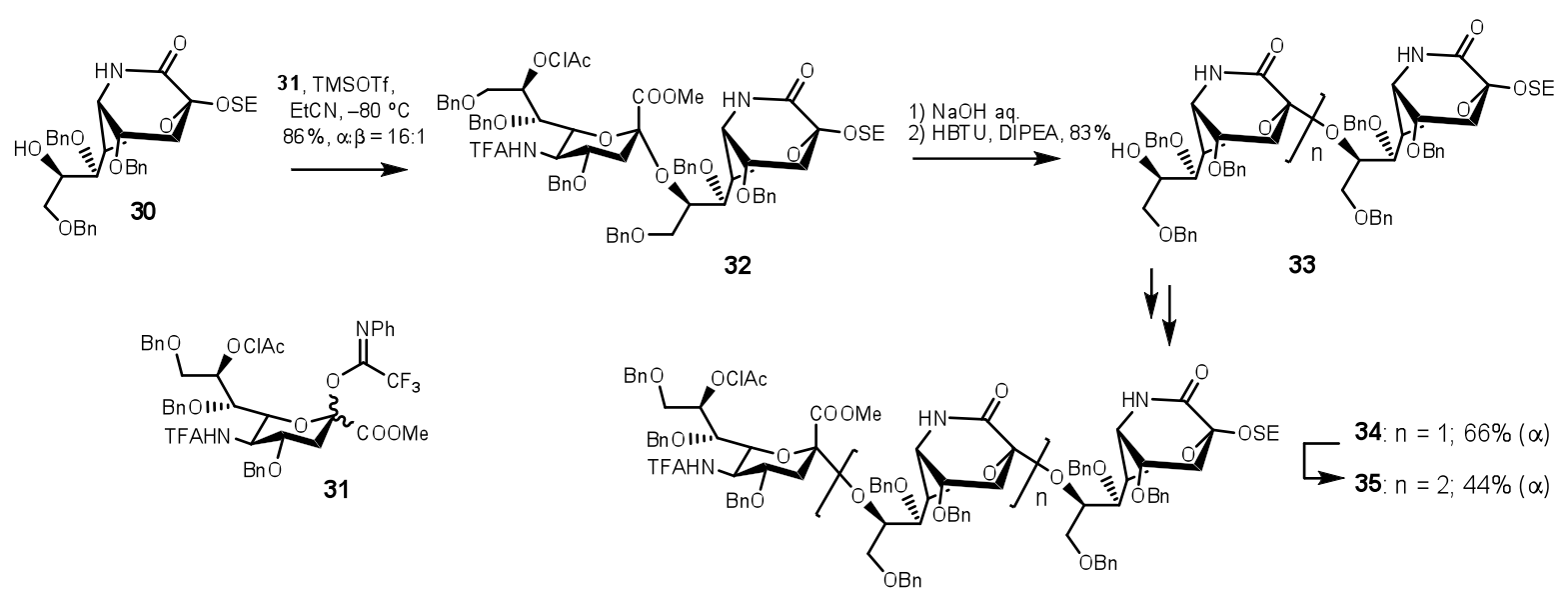

Scheme 5. Oligo $\alpha(2,8)$-sialic acid synthesis using 1,5-lactamized sialic acid acceptor 30 . DIPEA; diisopropylethylamine. 
phosphate (HBTU) the $\mathrm{C} 8-\mathrm{OH}$ liberated acceptor $\mathbf{3 3}$ was afforded in $83 \%$ yield. Under the intra-residual lactam formation reaction, the undesired $\beta$-anomer and the dehydro type byproduct are not able to form the lactam ring because of their configurations. Repetition of the synthetic cycles allowed for the synthesis of the $\alpha(2,8)$ oligosialic acid trimer $\mathbf{3 4}$ in 66\% yield and tetramer $\mathbf{3 5}$ in $44 \%$ yield in a highly stereoselective manner. The strategy has been applied to the synthesis of ganglioside. The $N$-lactamized concept is well summarized in a recent review (51).

\section{F. Synthesis of $\alpha(2,11)$ Oligosialic Acid Composed of Neu5Gc Units}

Neu5Gc is another abundant sialic acid structure in mammalian glycans although not in those of humans. For the synthesis of sialylglycans having Neu5Gc, similar strategies as in the case of the Neu5Ac building block are available including thioglycoside building blocks as well as phosphite leaving groups $(52,53)$. Neu5Gc structures are also able to obtain by transforming the above mentioned sialic acid building blocks having $N$-modifications.

$\alpha(2,11)$ Oligosialic acid is another possibility when Neu5Gc is the sialic acid. Such structures are in sea urchin glycans as well as at the non-reducing terminus of various unique gangliosides. The hydroxyl group on the glycoyl moiety (11-position) is sensitive to sialylation. The general strategy for the synthesis of $\alpha(2,11)$ connectivity is indicated in Scheme 6 (54-56). Instead of performing sialylation reactions for sialic acid chain elongation, a promising approach is to use amide condensation between the glycolic acid moiety and the 5-amino group. The most advantage of the strategy is that an $\alpha / \beta$ selectivity in sialylation does not influence for chain elongation. 5-Amino protection of Neu5Ac thioglycoside was transformed into $N$-Troc or Fmoc protection to give building block 36. Coupling with benzyl glycolate produced the common intermediate 37 with an $\alpha / \beta$ ratio of 7.5:1. The benzyl-ester of $\mathbf{3 7}$ was removed using $\mathrm{Pd}$ catalyzed hydrogenolysis in EtOAc to give carboxylic acid
こなうことで 8 位水酸基へ再びシアリル化するための受容体 33 を $83 \%$ の収率で導いた。残基内ラクタム形成反応の条件下 では、望まない $\beta$ 体やデヒドロ体副生成物はその立体配置か らラクタム化が困難であると考えられる。このサイクルを繰 り返すことで $\alpha(2,8)$ オリゴシアル酸 3 量体 $\mathbf{3 4}$ を $66 \%$ の収率、 4 量体 35 を $44 \%$ の収率でそれぞれ立体選択的に得ている。上 述の $N$ - ラクタム化受容体のコンセプトも含めたガングリオシ ドの合成戦略は近年発表された総説にまとめられている (51)。

F. Neu5Gc からなる $\alpha(2,11)$ オリゴシアル酸の合成

Neu5Gc は人を除く哺乳動物で広く存在するシアル酸分 子種である。Neu5Gcをもつシアリル化糖鎖を合成する場合、 Neu5Ac 供与体で用いた手法が利用可能であり、その脱離基と してはチオグリコシドやホスファイトなどが適用されてきた $(52,53)$ 。上述の $N-5$ 修飾型シアル酸供与体もまた、Neu5Gc 構 造に変換可能である。

$\alpha(2,11)$ オリゴシアル酸はNeu5Gc から構成されている。 グリコリル部位の水酸基 (ここでは 11 位とする)はシアリル 化を受けて抢り、そのような構造は前述のようにウニやユニー クなガングリオシドの非還元末端などにみられる。一般的な $\alpha(2,11)$ 結合形成の手法を Scheme 6 に示した (54-56)。シアル 酸鎖の伸長にグリコシル化反応を使う代わりにグリコール酸 部分と 5 位アミノ基の間でアミド縮合を使う手法が一般的で ある。この手法をとることでグリコシル化反応による $\alpha / \beta$ 選 択性に左右されずに鎖長が伸長できることが利点である。ま ずNeu5Ac のアミノ基を $N$-Troc や Fmoc 保護に変換してシア ル酸供与体 36 を得る。続くグリコール酸ベンジルとのグリコ シル化反応は共通中間体 37 を $\alpha / \beta$ 比 7.5:1 で与えた。37 のべ ンジルエステルは酢酸エチル中で Pd 触媒を用いた接触水素化 により除去し、カルボン酸 $\mathbf{3 8}$ をえた。また 37 を $\mathrm{Zn}-\mathrm{AcOH}$ で還元して Troc 基を除去してアミノ体 $\mathbf{3 9}$ を得る。化合物 $\mathbf{3 8}$ と39はアミド縮合により容易にカップリング可能で、このカッ

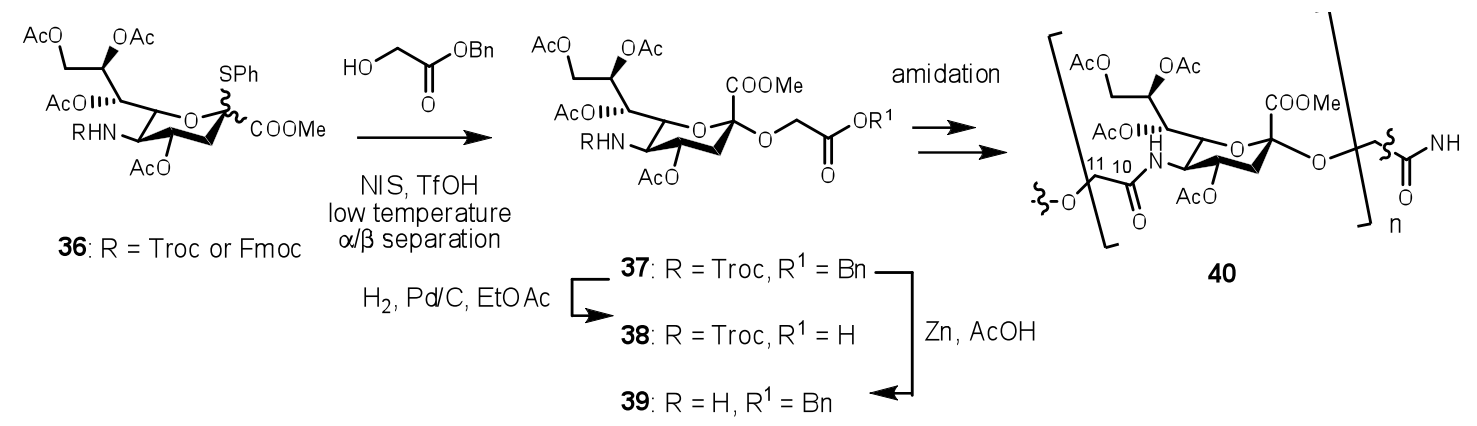

Scheme 6. General scheme for the synthesis of $\alpha(2,11)$ oligosialic acid 40 . 
38, and $\mathrm{Zn}-\mathrm{AcOH}$ reduction liberated the $\mathrm{N}-5$ amino group to give amine 39. The building blocks $\mathbf{3 8}$ and $\mathbf{3 9}$ were readily coupled by amide-condensations and subsequent protection and coupling processes gave $\alpha(2,11)$ oligosialic acids 40 . The strategy has also been applied to the synthesis of the unique starfish ganglioside LLG-3 $(57,58)$.

\section{G. Conclusion}

This review focused on very recent advances in stereoselective chemical sialylations and synthesis of natural sialylglycans using novel strategies, especially for the synthesis of oligo/polysialic acid structures. An artificial participation strategy using either a C-1 ester or a C-3 dehydro moiety shows good yields and stereoselectivity for relatively reactive primary acceptors including $\mathrm{C6}-\mathrm{OH}$ of galactoside. On the other hand, various $N-5$ modification strategies have been developed, which improve the reactivity as well as stereoselectivity of sialylation reactions. Remarkable results have been achieved with the 4,5-oxazolidinone type sialic acid building block. The integration of the experimental results indicates that 5 -amino modification augments the reactivity and $\alpha$-selectivity. However, the mechanism behind is not clear yet. Detailed analysis may help to develop further efficient sialic acid building blocks. The efficient sialylation directly expands the efficient synthesis of sialylglycans, which potentially leads functional analysis of the glycans based on chemical strategy.
プリング - 脱保護の過程を繰り返すことで $\alpha(2,11)$ オリゴシア ル酸 40 を与える。本手法はまた $\alpha(2,11)$ オリゴシアル酸構造を 非還元末端にもつヒトデガングリオシド LLG-3 の合成にも適 用されている $(57,58)$ 。

\section{G. 結 論}

本総説では特に最近の有機合成を用いた新規の手法によ る立体選択的シアリル化反応と、それらの手法を用いたオリ ゴ/ポリシアル酸構造の合成に焦点をあててまとめた。天然 構造にないような補助基を C-1 位にエステルで、または C-3 位 に導入する手法は特にガラクトースの 6 位を含む反応性の高 い1 級水酸基をもつ受容体で良好な立体選択性と収率を与え た。一方、5 位アミノ基の修飾に関しても多様な手法が開発さ れて、シアリル化反応に扔いて反応性ならびに立体選択性を 改善する結果となった。特に 4,5-オキサゾリジノン型供与体 は注目すべき良い結果を与えた。このような一連の実駼結果 は5 位アミノ基の修飾が反応性と立体選択性を高めることが できることを示しているが、その詳細なメカニズムに関して は全く不明である。この 5 位アミノ基修飾型供与体の詳細な 反応メカニズム解析を含めたシアル酸の化学の追求は、より 効率的なシアル酸供与体の開発につながる。効率的なシアリ ル反応は効率的なシアリル化糖鎖合成へ繋がり、その先には 化学的基盤にもとづいた糖鎖機能研究へとつながる可能性を 秘めている。

\section{References}

1. Angata, T., and Varki, A. (2002) Chem. Rev. 102, 439-469.

2. Ando, T., Ando, H., and Kiso, M. (2001) Trends Glycosci. Glycotechnol. 13, 573-586.

3. Angata, K., and Fukuda, M. (2010) Methods Enzymol. 479, 25-36.

4. Devi, S. J. N., Schneerson, R., Egan, W., Vann, W. F., Robbins, J.B., and Shiloach, J. (1991) Infect. Immun. 59, $732-736$.

5. Jennings, H. J., Roy, R., and Michon, F. (1985) J. Immunol. 134, 2651-2657.

6. Ferrero M. Á., and Aparicio, L. R. (2010) Appl. Microbiol. Biotechnol. 86, 1621-1635.

7. Lee, Y. S., Kubota, A., Ishiwata, A., and Ito, Y. (2011) Tetrahedron Lett. 52, 418-421.

8. Watson, D. C., Leclerc, S., Wakarchuk, W. W., and Young, N. M. (2011) Glycobiology 21, 99-108.

9. Tsvetkov, Y. E., Shashkov, A. S., Knirel, Y. A., and Zähringer, U. (2001) Carbohydr. Res. 335, 221-243.

10. Kitazume, S., Kitajima, K., Inoue, S., Troy, F. A. II, Cho, J.-W., Lennarz, W. J., and Inoue, Y. (1994) J. Biol. Chem. $269,22712-22718$.

11. Chen, X., and Varki, A. (2010) ACS Chem. Biol. 5, 163-176.

12. Boons, G.-J., and Demchenko, A. V. (2000) Chem. Rev. 100, 4539-4566.

13. Halcomb, R. L., and Chappell, M. D. (2002) J. Carbohydr. Chem. 21, 723-768.

14. Ando, H., and Imamura, A. (2004) Trends Glycosci. Glycotechnol. 16, $293-303$.

15. Takahashi, T., Tsukamoto, H., and Yamada, H. (1997) Tetrahedron Lett. 38, 8223-8226.

16. Ishiwata, A., and Ito, Y. (2003) Synlett 1339-1343.

17. Haberman, J. M., and Gin, D. Y. (2001) Org. Lett. 3, 1665-1668.

18. Haberman, J. M., and Gin, D. Y. (2003) Org. Lett. 5, 2539-2541.

19. Okamoto, R., Souma, S., and Kajihara, Y. (2008) J. Org. Chem. 73, 3460-3466.

20. Hanashima, S., Akai, S., and Sato, K. (2008) Tetrahedron Lett. 49, 5111-5114.

21. Demchenko, A. V., and Boons, G.-J. (1998) Tetrahedron Lett. 39, 3065-3068.

22. De Meo, C., Demchenko, A. V., and Boons, G.-J. (2001) J. Org. Chem. 66, 5490-5497.

23. Lin, C.-C., Huang, K.-T., and Lin, C.-C. (2005) Org. Lett. 7, 4169-4172.

24. Yu, C.-S., Niikura, K., Lin, C.-C., and Wong, C.-H. (2001) Angew. Chem., Int. Ed. 40, 2900-2903.

25. Tanaka, K., Goi, T., and Fukase, K. (2005) Synlett 2958-2962.

26. Ikeda, K., Miyamoto, K., and Sato, M. (2007) Tetrahedron Lett. 48, 7431-7435.

27. Tanaka, H., Adachi, M., and Takahashi, T. (2005) Chem. Eur. J. 11, 849-862.

28. Ando, H., Koike, Y., Ishida, H., and Kiso, M. (2003) Tetrahedron Lett. 44, 6883-6886. 
29. Tanaka, H., Nishiura, Y., Adachi, M., and Takahashi, T. (2006) Heterocycles 67, 107-112.

30. Hanashima, S., Castagner, B., Esposito, D., Nokami, T., and Seeberger, P. H. (2007) Org. Lett. 9, 1777-1779.

31. Hanashima, S., and Seeberger, P. H. (2007) Chem. Asian J. 2, 1447-1459.

32. Tanaka, S., Goi, T., Tanaka, K., and Fukase, K. (2007) J. Carbohydr. Chem. 26, 369-394.

33. Tanaka, K., Fujii, Y., Tokimoto, H., Mori, Y., Tanaka, S., Bao, G.-m., Siwu, E. R. O., Nakayabu, A., and Fukase, K. (2009) Chem. Asian J. 4, 574-580.

34. Lin C.-C., Adak, A. K., Horng, J.-C., and Lin C.-C. (2009) Tetrahedron 65, 4714-4725.

35. Tanaka, H., Nishiura, Y., and Takahashi, T. (2006) J. Am. Chem. Soc. 128, 7124-7125.

36. Crich, D., and Li, W. (2007) J. Org. Chem. 72, 7794-7797.

37. Farri, M. D., and De Meo, C. (2007) Tetrahedron Lett. 48, 1225-1227.

38. Kanie, O., Kiso, M., and Hasegawa, A. (1988) J. Carbohydr. Chem. 7, 501-506.

39. Schmidt, R. R., Behrendt, M., and Toepfer, A. (1990) Synlett, 694-696.

40. Tanaka, H., Nishiura, Y., and Takahashi, T. (2008) J. Am. Chem. Soc. 130, 17244-17245.

41. Tanaka, H., Nishiura, Y., and Takahashi, T. (2009) J. Org. Chem. 74, 4383-4386.

42. Tanaka, H., Tateno, Y., Nishiura, Y., and Takahashi, T. (2008) Org. Lett. 10, 5597-5600.

43. Crich, D., and Chandrasekhar, N. (2010) Angew. Chem. Int. Ed. 49, 3049-3052.

44. De Meo, C., and Priyadarshani, U. (2008) Carbohydr. Res. 343, 1540-1552.

45. Hanashima, S., Sato, K., Ito, Y., and Yamaguchi, Y. (2009) Eur. J. Org. Chem. 4215-4220.

46. Hanashima, S., Yamaguchi, Y., Ito, Y., and Sato, K. (2009) Tetrahedron Lett. 50, 6150-6153.

47. Hsu, C.-H., Chu, K.-C., Lin, Y.-S., Han, J.-L., Peng Y.-S., Ren, C.-T., Wu, C.-Y., and Wong, C.-H. (2010) Chem. Eur. J. 16, $1754-1760$.

48. Kanie, O., Ito, Y., and Ogawa, T. (1994) J. Am. Chem. Soc. 116, 12073-12074.

49. Ando, H., Koike, Y., Koizumi S., Ishida, H., and Kiso, M. (2005) Angew. Chem. Int. Ed. 44, 6759 -6763.

50. Tanaka, H., Ando, H., Ishida, H., Kiso, M., Ishihara, H., and Koketsu, M. (2009) Tetrahedron Lett. 50, $4478-4481$.

51. Ando, H., Ishida, H., and Kiso M. (2010) Methods Enzymol. 478, 521-540.

52. Hasegawa, A., Uchimira, A., Ishida, H., and Kiso, M. (1995) Biosci. Biotechnol. Biochem. 59, 1091-1094.

53. Hanashima, S., Tomiya, T., Ishikawa, D., Akai, S., and Sato, K. (2009) Carbohydr. Res. 344, 959-965.

54. McAuliffe, J. C., Rabuka, D., and Hindsgaul, O. (2002) Org. Lett. 4, 3067-3069.

55. Fan, G.-T., Lee, C.-C., Lin, C.-C., and Fang, J.-M. (2002) J. Org. Chem. 67, 7565-7568.

56. Ren, C.-T., Chen, C.-S., Yu, Y.-P., Tsai, Y.-F., Lin, P.-Y., Chen, Y.-J., Zou, W., and Wu, S.-H. (2003) Chem. Eur. J. 9, $1085-1095$.

57. Hanashima, S., Ishikawa, D., Akai, S., and Sato, K. (2009) Carbohydr. Res. 344, 747-752.

58. Tamai, H., Ando, H., Tanaka, H., Hosoda-Yabe, R., Yabe, T., Ishida, H., and Kiso, M. (2011) Angew. Chem. Int. Ed. 50, $2330-2333$.

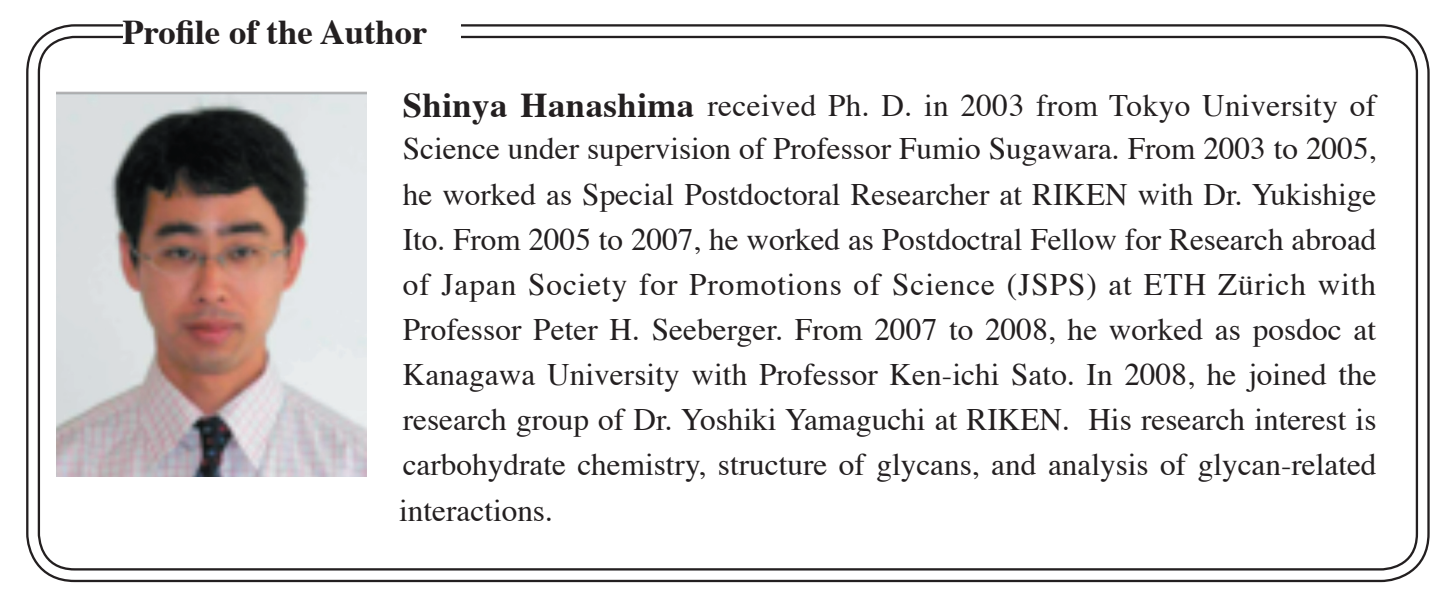

